\title{
凝固線溶面からみた肝転移の検討
}

特に肝硬変肝と正常肝について—

小代 正 隆* 西 満 正*

\section{Experimental studies of hepatic metastasis to normal or cirrhotic liver}

\author{
Masataka OJIRO* and Mitsumasa NISHI*
}

Key words: hepatic metastasis, liver cirrhosis, coagulofibrinolysis system, microcirculation

We have studied experimentaly the influence of coagulofibrinolysis system and platelet on the metastases of cancer.

In this series especially, the hepatic metastasis was investigated on the effect of liver cirrhosis. Cirrhosis was produced by $\mathrm{CCI}_{4}$ injection i.m., 2 times a week, for 6 months in rats.

Result ; Hepatic metastasis in liver cirrhosis after the intraportal injection of $\mathrm{AH} 130$ and $\mathrm{AH} 66 \mathrm{~F}$ cells, increased remarkably as compared to controls without cirrhosis.

The laboratoly findings of blood and tissue was examined during cirrhosis production.

At the early phase, fibrinogen and antiplasmin increased, but at the time of completed cirrhosis, fibrinogen and antiplasmin decreased inversely. At the time of tumor cells injection, cirrhosis groupes has a hyperfibrinogenemia, high level of antiplasmin and more high level of tissue thromboplastin activity than normal liver groups. Addly, intrahepatic portal vein branch of cirrhosis showed narrowing and stenosis by microangiography. Also, the hepatic metastasis increased in normal liver by injection of tumor cells added ADP (Adenosine diphosphoric acid).

Discussion; The increased incidense of hepatic metastasis may be due to the disturbance of microcirculation and hypercoagulability of blood and tissue.

Our clinical studies indicated of 38 cases with hepatic metastasis of gastric and colo-vectal cancer. 9 cases were present liver cirrhosis.

Therefore, we suggested that the hematogenous metastasis were influenced by

* 鹿児島大学医学部第一外科 (广 890 鹿児島市宇宿町1208-1), First Department of Surgery, School of Medicine, Kagoshima University, Kagoshima, Japan. 
coagulo-fibrinolysis system and platelet in the liver as well as the lung, and the difference between clinical and experimental studies was made on the phase of liver cirrhosis.

\section{はじめに}

癌の血行性転移は, 腫瘍緗胞 の性質，媒介体である血液の性 状, 着床する臟器の状態が関与 する．その因子として凝固線溶 系の影響，特に血小板が転移の 初期相において重要であること をわれわれは指摘して来た。今 まで，これらの実験モデルは血 行性肺転移による検討がほとん に゙である.われわれは門脈経路 の血行性肝転移について, 硬変 肝と正常肝を対象として，凝固 線溶および血小板の面から行っ た。

\section{I. 実験方法}

腫瘍は AH130 扰よび AH66F（佐々木研， 佐藤博先生より供与) を $1 \times 10^{6}$ 個, Donryu 系 雄ラット (150g 前後) の門脈飞注入, $4 \sim 5$ 日後殺して肝転移を光顕的に観察した. 肝硬变 ラットの作成は, $\mathrm{CCI}_{4}$ 0.3 0. $5 \mathrm{cc}$ 週 2 回筋注 により約 6 か月で, 組織学的に硬変肝が完成さ れた. ADP 添加実験は ADP 30r を腫瘍細胞 と混じ注入した。

凝血学的測定法：Fibrinogen 住 Thrombin time 法, 血小板数は Fonio 法, antiplasmin 活性は Plg. Free 平板に既知量の Plasmin t 混じ，その溶解阻止面積を％で表示. Tissue thromboplastin activity は Quick 一段法によ るプロトロンビン時間で, Tissue plg. activator activity は Astrup 変法により $2 \mathrm{M} \mathrm{KCl}$ で抽 出, Standard 平板で測定した.

血管構築は Microangio にて検討. 臨床検討 には胃癌, 結腸直腸癌, 食道癌で, 手術時肝転 移を認めた 38 例につき，肝硬変所見の有無を検 討した.

\section{II. 結 果}

1. 肝転移実験は $\mathrm{CCI}_{4}$ 中止後 $1 \sim 2$ 週内に 行ったが，AH130 は正常肝では10匹中 2 匹に 肝転移を認めた。それも転移結節数は 1 ～2 個 でかつ結節は小さかった．AH66F 証正常肝で 11 匹中 6 匹に転移を認めた。 $\mathrm{AH} 130$ 上 $\mathrm{AH} 66 \mathrm{~F}$ の転移結節は $\mathrm{AH} 130$ が限局型, すなわち境界 明瞭な型で， $\mathrm{AH} 66 \mathrm{~F}$ は比較的境界の不明瞭な 浸潤型を示した（図１）。な招肝転移を認めな かった例は肺に転移を認めた. 肝の転移場所は Sinusoid であることが組織学的に認められた。 一方硬変肝では $\mathrm{AH} 130$ および $\mathrm{AH} 66 \mathrm{~F}$ は全例 肝転移を形成した。しかもその結節数は正常肝 に比べ著明に多く，結節の大きさは硬変肝の転 移結節の方に大きいむのが多く認められた（表 1 ).

2. ADP 添加実験. ADP は腫瘍細胞に毒 性を示さず，ADP と腫瘍細胞を混注すると， 正常朋でも $\mathrm{AH} 130 ， \mathrm{AH} 66 \mathrm{~F}$ ともに著明な肝転 移を形成した。また腫瘍細胞および ADP の静 注により血小板数は著減するが，両者を混じた 場合はさらに血小板は静注後減少した。 


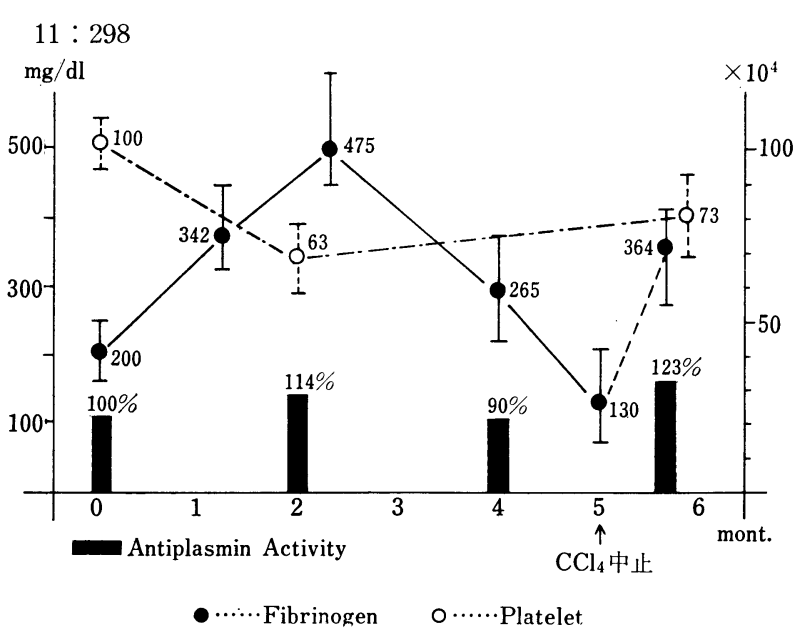

Fig. 2 Changes of fibrinogen, platelets and antiplasmin act

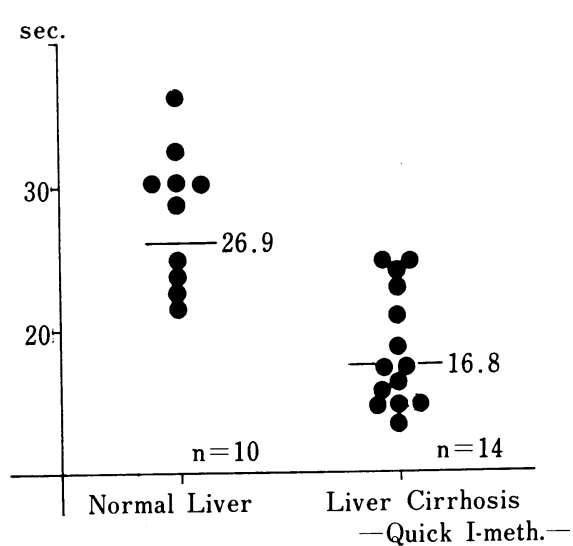

Fig. 3Tissue thromboplastin activity
3. 肝硬変作成過程の血中 Fibrinogen, antiplasmin 活性，血小板数の変動：図 2 のごと く， $\mathrm{CCl}_{4}$ 投与の初期では Fibrinogen および Antiplasmin 活性は上昇するが，肝硬変の完成 する頃になると，Fbrinogen は著減し，Antiplasmin 活性 屯低下，血小板数 も若干減少す る. このまま $\mathrm{CCI}_{4}$ 投与を続行すると腹水が貯 留し死亡する．投与を中止すると Fibrinogen は著増し，Antiplasmin 活性む上昇した。した がって肝転移実験は Fibrinogen および Antiplasmin 活性の増量した時期であった。

4. 組織凝固活性打よび線溶活性：肝と肺の Tissue thromboplastin activityは明らかに肺が 高く，正常肝と硬変肝とでは硬変肝の方が高か った（図了）。また Tissue plasminogen activator 活性は正常肝抒よび硬変肝とあに認められ なかった。

5. 門脈血管構築像：肉眼的にも硬変肝の門 脈は怒張し，microangioによる肝内門脈枝は正 常肝に比し, 細く狭少化し網状となり, 血液の 循環障害が疑われた。

\section{III. 考按}

悪性腫瘍の血行性転移に打ける凝固線溶系の 影響については多くの報告がみられる。われわ れは腫瘍細胞の着床機序に凝固線溶が影響し中 でも血小板の重要性を指摘した ${ }^{1)}$. 一方田中ら は腫瘍細胞自体の凝固線溶能の関連を指摘して いる2゙. しかしこれらの実験は肺転移で検討さ
Table 1 Hepatic metastasis of AH130 and $\mathrm{AH} 66 \mathrm{~F}$

\begin{tabular}{c|c|c}
\hline & Normal liver & Liver cirrhosis \\
\hline AH130 & $2 / 10$ & $11 / 11$ \\
AH66F & $6 / 11$ & $10 / 10$ \\
\hline
\end{tabular}

れたあのであるまた臟器の特異性む考えられ ることから，今回，肝転移の検討を行った。確 かに AH130 と AH66F では肝転移の有無だけ でなく，その形態も異なった。しかし硬変肝で は両者之屯，全例転移を認め，その結節数屯著 明に多かった。乙の事実は Fisher が Walker carino sarcoma を用いて同じ結果を得てい $る^{3)}$ ．その原因として Fisher は門脈の血行と， 肝より何らかの物質を推察しているのみであ る.凝固線溶面からみれば，乙の実験系では Fibrinogen の著増, Antiplasmin 活性の上昇が 血液にあり，肝組織には線溶活性はなく，凝固 活性の上昇がある。しかも門脈の血管は細く狭 小化し循環の障害がある。乙れらの事実は血栓 を作り易い状態にあるといえる，また正常肝で む $\mathrm{ADP}$ を添加して，血小板機能を賦活するこ とで転移が形成された。しかも血小板数の減少 が腫瘍単独の静注による減少率に比へ ADP 添 加腫瘍の静注の方が高いことからも，血小板の 働き屯無視できないと考える。

われわれは今まで，肺転移実験において Fibrinogen を減少させること年や，血小板機能 


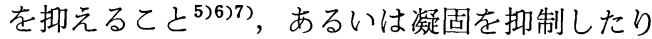
線溶を六進させることにより肺転移を抑制し た。 また脾摘出による血小板数増量状態では逆 に肺転移の著増を認めること等を報告した．肝 転移屯血行性肺転移之同様に，今回の実験によ り凝固線溶，血小板の影響を受けると考えられ る. 臨床上の問題としては, 手術時, 正常肝へ 転移する比率に比へ，肝硬変を合併した転移症 例は 38 例の内 9 例で約 $25 \%$ でしなかった. し かし逆に肝硬変患者に転移が多いかどうかは問 題である. 臨床上肝硬変では Fibrinogen は減 少し，線溶の六進がみられるとの報告が多いて とから，乙の実験之同一視する訳にはいかない とも考えられる．また肝硬変のタイプや，時期 にも問題があろう.

\section{文献}

1）小代正隆, 西 満正：癌細胞発育, 転移につ
いての血小板, 凝固線溶学的考察. 第 16 回プ ラスミン研究会報告集, $77,1976$.

2）児玉好夫, 田中健蔵：ラット腹水癌の凝固線 溶. 医学のあゆみ, 83 (8)；530, 1972.

3) Fisher, E.R.: Experimental studies of factors influencing hepatic metastasis. Cancer, $31 ; 860,1960$

4) 西 満正, 小代正隆：担癌体の Fibrinogen の 意義における実験的考察. 癌と化学療法, 5 (Suppl. 1) ; 147, 1978.

5) Gastpar, H. : Inhibition of cancer cell stickness by the blocking of platelet aggregation. S. Af. Med. J., 48; 621, 1974.

6) Hilgard, P.: The role of blood platelets in experimental metastasis. Br. J. Cancer, $28 ; 429,1973$.

7）小代正隆，西 満正：癌細胞発育, 転移につ いての血小板, 凝固線溶学的考察一続報一. 第17回プラスミン研究会報告集, $57,1977$.

\section{○細胞分化の正常亡異常! \\ 血液細胞の分化と增殖一基硙と臨床}

編集 自治医科大学学長 中尾喜久 自治医科大学教授 高久史䵇

専門医21氏分担執筆

\section{A 5 判 251頁 図126 表47 定価4,800円(广200円)}

血液細胞とその分化は近年における血液学の中で最も目覚ましい発展をとげた分野であ る。造血藏器では分化という過程が胎生期のみならず成体にも営まれ, 現在医学の当面し ている重大な問題である「細胞の癌化」にも密接な関係をもっている。本書は今までの歴 史的展望，世界の現況を概説し，わが国での第一線の優れた研究をまとめた良書である。

○内客 : 1. 幹細胞研究の歴史的展望, 2 . 骨䯣增殖性疾患における幹細胞の変動, 3.小児血液疾患における 造血幹細胞の動態, 4.Erythropoietin研究の最近の進少, 5.赤血球系細胞の分化, 6.造血幹細胞の增殖分 化機構の異常としての白血病発症機構の実験的研究, 7.㽷エリトロポエチンの免疫化学的研究, 8.造血幹 細胞の増殖に及ぼす各種異種抗血清の影響, 9.無形成骨䈯の造血回復機構一大動脈吻合パラビオ一ジスに よる白血球分化の研究一, 10. 造血の“場”の概念とその役割, 11 . 造血細胞のピリミジン代謝調節, 12. 造

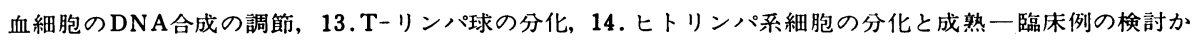
らの考察一。 